\title{
INSECTS INJURIOUS TO MAN AND STOCK IN ZANZIBAR.
}

\author{
By W. M. Aders.
}

\section{Order DIPTERA.}

\section{Culicidae.}

Zanzibar Town is roughly divided into two halves, the European quarter, with the Indian Bazaar, and the native African town, these two districts being separated by a tidal creek. The European quarter (where most of the Government officials and Europeans reside) is on the western side in close proximity to the sea. The periphery of the town is surrounded on the land side by various swamps, all of them potential mosquito-breeding areas during certain seasons of the year, some of them permanent throughout the year.

There are two rainy seasons during the year ; the heavy rains generally commence about the middle of April and last until the end of May or the first week in June. The rainfall for April, May and June during the last three years was as follows :-

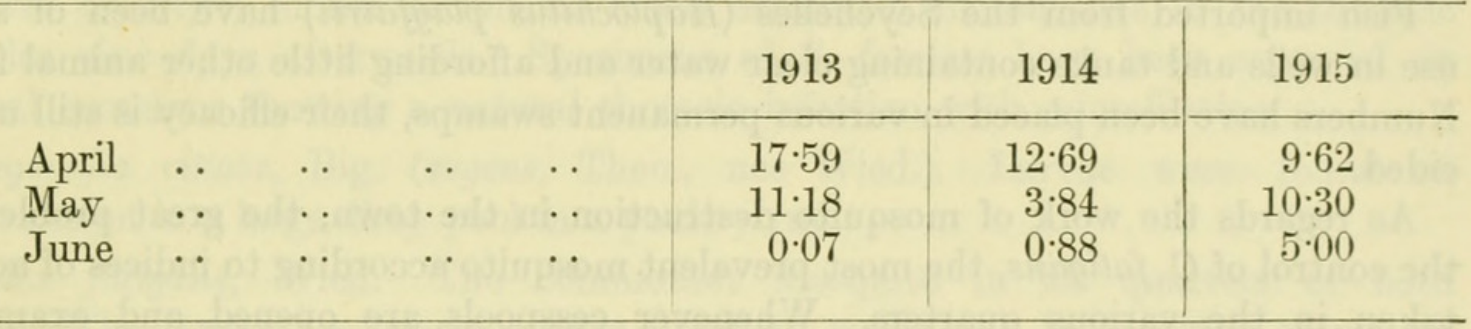

The small rains break about November and are of three weeks duration. These two rainy seasons greatly influence the prevalence in town of Anophelinae and various species of Culicinae. During the dry season Anophelinae are of rare occurrence in the town, one might say practically non-existent, judging by the mosquito brigade returns. There are certain permanent Anopheline breeding grounds outside, and on the periphery of the town; shortly after the rains set in, a chain of small swamps, pools, etc., are brought into being, which act as intermediate breeding grounds for Anophelines and are responsible for their eventual arrival in the town. During May and June Anopheline larvae are found in small numbers throughout the town ; as their breeding grounds dry up the adults die off, to reappear during the next rainy season.

The following table shows the catches of Anopheline larvae in the town during April, May and June for the last three years :-

\begin{tabular}{lllll|c|c|c}
\hline & & & & & 1913 & 1914 & 1915 \\
April & $\ldots$ & $\ldots$ & $\ldots$ & $\ldots$ & 3 & 3 & 2 \\
May & $\ldots$ & $\ldots$ & $\ldots$ & $\ldots$ & 14 & 8 & 9 \\
June & $\ldots$ & $\ldots$ & $\ldots$ & $\ldots$ & 5 & 7 & 4 \\
\hline
\end{tabular}


To sum up the position. During certain periods of the year Anophelines gain entrance to the town through a line of small collections of water formed by the rains ; these temporary breeding places soon dry, with the result that most of the adult Anophelines in town die. There are permanent breeding grounds outside the town which constitute the real home of these mosquitos.

For the purpose of controlling mosquito larvae, several of the larger swamps on the periphery of the town have been drained, others brought into existence during the rainy season are oiled, and a mosquito brigade works under the supervision of the medical officer of health.

During the last few years three kinds of traps have been used for collecting larvae of Anophelines, Culicines and Stegomyias, respectively. The Anopheline trap consists of a flat tub about six inches in height filled with rain-water and algae, with a small layer of earth sprinkled on the bottom. The Culicine trap consists of a half barrel filled with water rich in decaying vegetation; the addition of cess-pool water, rice or other organic material forms an attractive bait. The Stegomyia trap is made in the same way as the former, being filled with clean rainwater. I am of opinion that if these traps were used on an extensive scale, they would undoubtedly prove of great use as one method of mosquito eradication.

Fish imported from the Seychelles (Haplochilus playfairii) have been of some use in wells and tanks containing clear water and affording little other animal food. Numbers have been placed in various permanent swamps, their efficacy is still undecided.

As regards the work of mosquito destruction in the town, the great problem is the control of $C$. fatigans, the most prevalent mosquito according to indices of adults taken in the various quarters. Whenever cesspools are opened and examined numbers of $C$. fatigans larvae are found, generally in pure culture, except in cases where the water is very foul, when the larvae of Pericoma meridionalis reveal themselves. These small Psychodidae are a common feature in bathrooms and closets throughout the town.

Practically all houses are furnished with cesspools and cesspits, those of Europeans being provided with earth-closets on the bucket system. The cesspools contain kitchen, bath and household waste water, and in some instances receive a certain amount of storm water. Generally an opening leads from the pantry on the groundfloor direct into the cesspool, affording easy entry for adult mosquitos; the roofs of the cesspools are also often faulty, thus providing entry for mosquitos.

Larvae of S. fasciata are found throughout the town area, particularly in native huts, where water is stored in large earthenware jars, but also in the iron drums and water-barrels of the Indian bazaars and European quarters. The careful collection of adult mosquitos in houses and their detailed classification and enumeration has proved of the greatest value in the search for and the control of breeding places.

The following natural enemies of mosquitos have been recorded :-

Larvae of dragon-flies, water-bugs (many species), and larvae of various aquatic Coleoptera. Experimentally the aquatic bugs have proved to be the most rapacious. Nightjars, bats and various species of spiders belonging to the family ATTIDAE prey on the adults. 


\section{The Mosquitos of Zanzibar Town.}

Anopheles costalis, Lw. The only Anopheline taken in the town area. Larvae are generally found in shallow pools rich in decaying vegetation and algal growth, occasionally in water fountains, tin drums, rain-water left in dug-out canoes and crab-holes. They are able to thrive in pools exposed to direct sunlight. Larvae in captivity are difficult to rear, unless under suitable and natural conditions; many become infested with Vorticella and speedily succumb to this infection. This is the common vector of malaria in Zanzibar, and sporozoits have been found on several occasions in the salivary glands. A. funestus, a much rarer species, has not yet been found infected, but only a small number of adults have been captured.

Stegomyia fasciata, F. This species is to be found everywhere, breeding under the most varied conditions, generally in household utensils, old tins, earthenware jars, etc. They show a marked preference for clear water, being rarely taken in association with Culex fatigans. Some of their rarer haunts are holes in mango trees and slots cut in the trunks of coconut palms to facilitate climbing. The larvae of $S$. fasciata are very hardy and able to exist in water with a very poor food supply. Experimentally larvae mature and pupate in water to which $2 \%$ of seawater has been added. Adults fed on a patient showing numerous microfilariae (Filaria bancrofti) in his peripheral blood exhibited microfilariae in the thoracic muscles nine days afterwards. Specimens of $S$. fasciata have been captured on several occasions showing a natural thoracic infection with microfilariae.

Stegomyia vittata, Big. (sugens, Theo., nec Wied.). Larvae were found on one occasion in a large dirty pool in a poultry run.

Culex fatigans, Wied. The commonest mosquito in all quarters of both towns. The larvae are nearly always found in water rich in decaying animal or vegetable matter, and are very common in cesspools. Large numbers of adults have been found to contain microfilariae (Filaria bancrofti), showing both thoracic and proboscis infections. Experimentally these mosquitos are difficult to feed in captivity, as they do not bite at all readily; they feed better about an hour before dawn. Larvae thrive and pupate in water to which $1 \%$ of common bar soap or $1 \%$ human urine has been added.

Culex tigripes, Grp. A considerable number of these useful larvae have been taken throughout the town in association with C. fatigans, S. fasciata and A. costalis, They are capable of destroying large numbers of mosquito larvae; I have seen two adult larvae destroy thirty Stegomyia larvae in an hour. Adults have never been taken in houses, and in captivity will not feed on blood. In a mixed collection of larvae $C$. tigripes can be easily detected by their almost Anopheline position in the water and generally white colour.

Eretmopodites quinquevittatus, Theo. Larvae are common in small dirty collections of water, especially in empty Molluscan shells; those of the land snail, Achatina panthera, nearly always harbour a number of these larvae. Adults have never been captured in houses, but are common in low bush and wooded areas. I have never been able to induce adults to feed on human blood in captivity. They partake greedily of banana and dates, and when fed on such a diet females have been shown to lay fertile eggs. The eggs, which are of a dark brown colour, are laid 
singly. The larvae are easily recognisable by the long narrow abdomen and thorax, short syphon, and the peculiar habit of gliding and not wriggling as a means of progression through the water. By this characteristic they are easily singled out from a mixed sample. The pupae are generally white in colour; the abdominal segments, instead of being coiled upwards towards the thorax, hang vertically downwards; conspicuous tufts of bristles attached to the anal fins are recognisable with the naked eye.

Eretmopodites chrysogaster var. subsimplicipes, Edw. A few specimens taken with and under the same conditions as $E$. quinquevittatus.

\section{The Mosquitos of Zanzibar and Pemba Islands.}

Anopheles costalis, Lw. This is the most abundant Anopheline in the island and has been found in every district. Larvae have been captured under very varied conditions, generally in small swamps and occasionally at the edges of large lakes and rivers. They seem to show a marked preference for the water in the shallow surface wells which are dug by the natives all over the island, this water being of a distinctly milky appearance from suspended clay. Some of their rarer haunts are brackish coral rock-pools, crab-holes, etc.

Anopheles funestus, Giles. Adults are common in native huts in outlying districts in proximity to flooded rice-fields; several have been taken in houses belonging to Europeans in Pemba. Larvae are generally found in flooded rice-fields and in large shallow swamps, also in backwaters of various rivers.

The distribution of this Anopheline is nothing like so general as that of $A$. costalis.

Anopheles mauritianus, Grp. Wild adults have never been captured. The larvae inhabit large swamps, often in association with $A$. costalis and $A$. funestus. They are easily recognised by their conspicuous abdominal banding and their habit of twisting themselves into an $\mathrm{S}$ formation while on the surface of the water.

Anopheles squamosus, Theo. Larvae have been taken in various large swamps in association with $A$. mauritianus and Culex laurenti. I am unable to distinguish between the larvae of this form and that of $A$. mauritianus.

Stegomyia fasciata, F. As mentioned before, one of the commonest forms in the town. It has been recorded from every district in the island; several islands at a considerable distance from Zanzibar are heavily infested.

Stegomyia vittata, Big. A rare form, I have only two records of breeding places.

Stegomyia metallica, Theo. Has been captured in various localities ; in every instance the larvae were obtained from holes in African almond trees (Terminalia catappa) and mango trees.

Stegomyia simpsoni, Theo. Like the last-named species, found breeding in African almond trees, but not so prevalent. A few were taken in an earthenware pot in association with S. fasciata.

Culex fatigans, Wied. Distributed all over the island.

Culex invidiosus, Theo. Common in swamps in association with Anopheles costalis.

Culex tigripes, Grp. Common all over the island. The larvae are capable of living under the most varied conditions; I have found them in swamps, old tins, waterholes and in holes in trees. 
Culex laurenti, Newst. Larvae abundant in swamps and water-holes, often in association with $A$. costalis.

Culex decens, Theo. Larvae have been taken in various breeding places, such as old tins, water-holes, road puddles, etc.

Culex univittatus, Theo. Larvae from rice swamps in association with Anopheles funestus.

Culex sitiens, Wied. A common species; adults have been captured in native huts in numerous villages.

Culex duttoni, Theo. Has a wide distribution. The larvae are easily recognisable by the dark ring near the apex of the siphon and its peculiar torpedo-like shape.

Culex perfuscus, Edw. Adults were captured in a cell in the central jail, the females being heavily engorged with blood. The jail is outside the town.

Culex simpsoni, Theo. Larvae were found in swamp water in company with a large number of other species, including Anopheles costalis.

Culex insignis, Cart. One record from a swamp area outside the town.

Culex tritaeniorhynchus, Giles. One record from an area outside the town.

Culiciomyia nebulosa, Theo. An extremely common form, and a very troublesome biter; larvae have been obtained from swamps and domestic utensils. A constant characteristic of the larva seems to be the six pairs of hair-tufts on the siphon.

Ochlerotatus pembaensis, Theo. Adults have been taken all along the sea-shore for several miles in proximity to the town; they are virulent biters. In Weti, the capital of Pemba Island, they are one of the commonest house mosquitos. Larvae abound in crab-holes and depressions close to high-water-mark, and are able to withstand a high degree of salinity; I have never found them actually in sea-water. Experimentally they thrive in water to which $80 \%$ of sea-water has been added. This species seems to be confined to the sea littoral, as we have no records of larvae from inland waters. The larvae are long-lived and grow slowly, the average length of life under normal conditions being 12 to 14 days. The characters of the larva are as follows :-

Head small, light brown in colour, with one small plumed hair above the eye. Antennae long, cylindrical, with hair-tuft on the dorsum of the basal joint and single long hairs at its apex. Thorax with long plumose hairs; the median tufts set in chitinous sclerites are remarkably long, being easily visible to the naked eye, and help to distinguish this form in a mixed collection. Abdomen with long plumose hairs on the first two segments, the remainder with single hairs. Comb difficult to see, triangular in outline, with a large number of pronged teeth. Siphon about as long as the 7 th and 8 th abdominal segments, not markedly pointed; pecten with 12 teeth, the 6 basal ones short. Anal segment furnished with a broad prominent beard composed of 8 long plumes.

Ochlerotatus durbanensis, Theo. A small series bred from larvae obtained from a rain-water pool in the neighbourhood of the town.

Ochlerotatus nigeriensis, Theo. Larvae obtained from rain pool in association with A. costalis. 
Ochlerotatus longipalpis, Grünb. All larvae of this species have been obtained from holes in mango trees in association with Toxorhynchites brevipalpis. The larvae have a peculiar faint rose colour, and are easily recognised by their habit of hanging suspended for considerable periods of time in the middle of their breeding water. All attempts to feed adults on human blood failed. The characters of the larva are as follows:-

Head large, dark brown in colour, with prominent well-developed brushes, the lateral clypeal hairs bifurcated; maxillae well developed, pendant and supplied with brushes. Antennae long, cylindrical, with one hair near the apex of the basal joint. Thorax small in comparison with the head, having the usual plumes, the median one slightly longer than the others. Abdomen with plumes on the first two segments ; the comb composed of 30 to 40 small scales. Siphon straight, as long as the 6th, 7 th and 8 th segments; pecten with 26 teeth.

Ochlerotatus fulgens, Edw. A few specimens were bred from larvae captured in a hole in a mango tree, and were mistaken for $O$. longipalpis.

Ochlerotatus irritans, Theo. Has been taken from various localities, chiefly in large swamps.

Ochlerotatus albocephalus, Theo. One record.

Ochlerotatus adersi, Edw. Larvae were taken in holes in African almond trees in association with Stegomyia metallica.

Eumelanomyia inconspicuosa, Theo. Larvae obtained under the same conditions as the former species.

Banksinella lineatopennis, Ludl. A rare form, represented in our collection by two specimens.

Cyathomyia fusca, Theo. Larvae taken in tree-holes.

Eretmopodites quinquevittatus, Theo. As previously mentioned, common in the town, also recorded from various out-districts.

Eretmopodites chrysogaster var. subsimplicipes, Edw. A few specimens taken with Eretmopodites quinquevittatus.

Mansonioides uniformis, Theo. No records from Zanzibar, but several adults have been captured on the island of Pemba in association with Anopheles funestus.

Toxorhynchites brevipalpis, Theo. Ubiquitous; we have specimens from many localities, including the town. Nearly every mango tree with holes in the trunk harbours from three to eight larvae. They are predaceous on larvae of $A$. costalis, S. fasciata, and C. fatigans; but as these three species are rarely found under such conditions, the Toxorhynchites is not of much practical value.

Mimomyia mimomyiaformis, Newst. Recorded from one locality.

Mucidus mucidus, Karsch. Adults have been taken in houses in close proximity to the town. Larvae were found on only one occasion, in an old cement tank containing water rich in decaying vegetation.

Taeniorhynchus fuscopennatus, Theo. Adults have been captured in houses in Pemba, the females heavily engorged with blood. No specimens have been recorded from Zanzibar Island. 


\section{TABANIDAE.}

Many species of these flies have been taken from various districts in both islands (Zanzibar and Pemba). They are found in abundance in wooded areas close to streams or marshes. I have captured very few species in open arid or grassy country. One record exists of a capture of two Tabanus biguttatus in the Government stables in the town. Their prevalence varies with the seasons, and they are very abundant for about six weeks after the rains. Ideal weather conditions are slight showers of rain with sunny interludes; on such a day the bag is always full. During heavy rain or high wind they are conspicuous by their absence.

TABANIDAE have not been definitely implicated in the spread of disease in Zanzibar, but there is a certain amount of evidence that they are capable of acting as vectors of Trypanosoma pecorum, the common trypanosome of stock in the island. Repeated efforts have been made to prove this experimentally; but owing to the extreme difficulty of keeping these flies alive in captivity and inducing them to bite experimental animals, no results have been forthcoming.

Tabanus taeniola, P. de B. This is the commonest Tabanid in the two islands, being found everywhere. They often attack man, flying on board the mail steamer while anchored at Pemba and inflicting severe bites on the passengers and crew. When alighting on cattle they nearly always select the lumbar region, seldom the legs. Engorgement averages $2 \frac{1}{2}$ to 3 minutes. In mixed herds of cattle and domesticated buffaloes the latter are always singled out for attack, as they seem more callous to the bites.

Tabanus taeniola var. variatus, Walk. This variety has only been taken occasionally, the typical $T$. taeniola being the common form.

Tabanus fraternus, Macq. A very common species, being found throughout the two islands. They often attack man, their feeding habits being like those of T. taeniola.

Tabanus par, Walk. This small species has a wide distribution throughout the two islands. It nearly always feeds on the withers and hocks of cattle.

Tabanus gratus, Lw. Quite a common species; large numbers have been taken in various districts on both islands.

Tabanus africanus, Gray. This handsome insect is by no means common, and its distribution and prevalence seem to be influenced both by season and environment. All records of capture are shortly after the rains and only in districts where streams are prevalent.

Tabanus biguttatus, Wied. A common species. It generally feeds on the hump of cattle, seldom attacking any other part. Engorgement in some cases took $4 \frac{1}{2}$ minutes. Males were taken on tree-trunks in proximity to grazing grounds.

Tabanus conspicuus, Ric. A rare species; only one female has been taken.

Tabanus thoracinus, P. de B. An uncommon form; our collection comprises only four specimens.

Tabanus ditaeniatus, Macq. Nowhere very abundant; all our specimens were taken shortly after the rains.

Tabanus leucostomus, Lw. Represented by two females in our collection. 
Tabanus producticornis, Aust. One specimen captured on the sea-shore near a mangrove swamp.

Tabanus albipectus, Big. A few specimens obtained from a sandy bank near the sea-shore.

Aegophagomyia pungens, Aust. A common species along the littoral of both islands. These insects seem to have a marked preference for damp sandy patches, often alighting to drink ; in comparison with other species they are but little affected by high wind. I have no record of their attacking man, but on several occasions they have been noticed feeding on goats.

Adersia oestroides, Karsch. Similar in its habits to Aegophagomyia pungens; numbers have been taken in close proximity to carcases of cattle. Never known to bite man.

Haematopota decora, Walk. The only species of this genus taken in Zanzibar. It is prevalent throughout the whole year on both islands, and generally feeds on the hocks and withers of cattle; engorgement averages $2 \frac{1}{2}$ minutes. This insect lives moderately well in captivity, and has been used on many occasions for transmission experiments.

Chrysops longicornis, Macq. A very common species in both islands, persistent throughout the year. Many specimens were taken in a deep shady valley in Pemba ; as many as thirty were captured in a few minutes on one donkey, its withers and hocks being smothered. Once they have started feeding nothing disturbs them, and they must almost be brushed off. Fully engorged specimens are slow of flight, proceeding a few yards, then settling on any convenient foliage. They readily attack man, inflicting painful bites round the ankles.

The following is a chart showing the seasonal incidence of the common TABANIDAE. In all cases the collections were made from two water-buffaloes, two hours being devoting to collecting. The majority were obtained from the Bububu district.

\begin{tabular}{|c|c|c|c|c|c|c|c|c|c|c|c|c|}
\hline & Jan. & Feb. & Mar. & April. & May. & June. & July. & Aug. & Sept. & Oct. & Nov. & Dec. \\
\hline Tabanus fraternus & 28 & 18 & - & 33 & 30 & 20 & 19 & 14 & 13 & 12 & 5 & 18 \\
\hline , toniola & 13 & 14 & - & 46 & 95 & 22 & 22 & 13 & 4 & 19 & 12 & 5 \\
\hline par & 3 & 1 & - & 17 & 17 & 9 & 10 & 1 & 1 & 9 & 5 & \pm \\
\hline gratus & 3 & 2 & 一 & 4 & 11 & 9 & 10 & 2 & 2 & 2 & 8 & 1 \\
\hline Hamatopota decora & 5 & 2 & - & 2 & 4 & 6 & 3 & 一 & 3 & 4 & - & 一 \\
\hline Tabanus biguttatus & 3 & - & 一 & 4 & 2 & 6 & 4 & 一 & 一 & 一 & 1 & 1 \\
\hline africanus & - & - & - & 4 & 3 & 1 & 1 & 一 & - & - & - & 1 \\
\hline leисовtoтиs & 一 & - & - & - & 1 & 1 & - & 一 & - & - & 1 & - \\
\hline ," ditaniatus & 一 & 一 & 一 & 一 & $\overline{1}$ & 2 & $\overline{3}$ & 二 & 二 & 3 & 二 & 1 \\
\hline $\begin{array}{l}\text { Chrysops longicornis } \\
\text { Tabanus conspicuus }\end{array}$ & - & 二 & 二 & 二 & - & $\begin{array}{l}3 \\
1\end{array}$ & - & 二 & - & 二 & 二 & 1 \\
\hline
\end{tabular}

$\begin{array}{lllrllllll}\text { January } & \ldots & \ldots & \ldots & 0.39 & \text { July } & \ldots & \ldots & \ldots & 0 \cdot 31 \\ \text { February } & \ldots & \ldots & \ldots & 1 \cdot 37 & \text { August } & \ldots & \ldots & \ldots & 0 \cdot 88 \\ \text { March } & \ldots & \ldots & \ldots & 9 \cdot 99 & \text { September } & \ldots & \ldots & \ldots & 2 \cdot 58 \\ \text { April . . } & \ldots & \ldots & \ldots & 17 \cdot 59 & \text { October } & \ldots & \ldots & \ldots & 4 \cdot 22 \\ \text { May .. } & \ldots & \ldots & \ldots & 11 \cdot 18 & \text { November } & \ldots & \ldots & \ldots & 3 \cdot 20 \\ \text { June .. } & \ldots & \ldots & \ldots & 0.07 & \text { December } & \ldots & \ldots & \ldots & 1 \cdot 31\end{array}$




\section{Muscidae.}

Stomoxys calcitrans, L. Occurs everywhere in the island where cattle are found. Larvae have been found in recent moist droppings ; manure pits swarm at all times of the year with larvae and pupae. Animals somewhat out of condition are especially singled out for attack, and this is a useful diagnostic sign when looking over a herd for a suspected trypanosome case. The following non-biting Muscids have been noticed feeding in association with $S$. calcitrans, licking the droplet of blood left from the Stomoxys puncture:-Musca domestica, Pycnosoma putorium, and Biomyia tempestatum.

Stomoxys nigra, Macq. Not so common as the preceding species, but recorded from numerous localities in both islands.

Lyperosia minuta, Bezzi. These small flies are somewhat local in their distribution, showing a marked preference for open windy steppe country; conditions not favoured by other blood-sucking flies.

Cordylobia anthropophaga, Grüb. The only fly known to cause cutaneous myiasis in man in Zanzibar. Several larvae have been obtained from human beings, others from dogs, rabbits, and guinea-pigs. The pupal stage averages about 19 days.

Musca domestica, L. Found in houses and around rubbish heaps throughout the year, though Zanzibar town is remarkably free from these filth feeders. Their favourite breeding grounds are manure pits containing fermenting horse and donkey dung; I have seldom found larvae in cattle manure.

Lucilia sericata, Mg. A few specimens taken on meat in the public market.

Pycnosoma putorium, Wied. Abounds at all seasons of the year in the public markets, being especially attracted to fish stalls and less prevalent on meat. Larvae are found in garbage containing decomposing meat and fish. I have noticed them only occasionally feeding on human ordure.

Pycnosoma marginale, Wied. Not so numerous as $P$. putorium, but commoner on the meat stalls. Breeds in decomposing carcasses and meat.

Pycnosoma bezzianum, Villeneuve. Larvae have been taken on several occasions from donkeys' ears and from sores. In all such cases much destruction of superficial tissue had taken place, associated with pus formation.

Sarcophaga sp. Numbers are always to be found around cess-pits and privies. Larvae abound in rotting meat and carcasses ; chicken entrails are generally thrown away carelessly, and if not picked up by crows or cats become a potential breeding nidus for various species of Sarcophaga.

Synthesiomyia brasiliana, Br. \& B. Large numbers have been bred from decomposing rats' carcasses.

\section{Oestridae.}

Oestrus ovis, L. Large numbers of larvae have been taken from the frontal sinuses of goats; in some cases they had penetrated to the base of the horn, but they do not seem to cause any appreciable damage to their hosts. The pupal stage averages 19 days. Very common throughout the island.

Gastrophilus asininus, Br. A few adults have been taken flying around cattle and donkeys. 


\section{Drosophilldide.}

Drosophila sp. Very prevalent hovering over ripe fruit, in which they breed. At times they alight on meat and human excrement.

\section{Hippoboscidae.}

Hippobosca maculata, Leach. Common on cattle, horses and donkeys. The number of Hippoboscids taken has been surprisingly few, and I am of opinion that a moist damp climate like that of Zanzibar is inimical to their development.

Hippobosca capensis, Olf. Has been recorded by a previous collector, I have captured no specimens.

Ornithoeca podicipis, Rod. Taken from a species of heron.

Lynchia maura, Bigot. Common on domesticated pigeons. Numbers of wild pigeons and doves have been examined with negative results.

Cyclopodia greefi, Karsch. Very abundant on flying foxes (Pteropus voeltzkowi).

\section{Order SIPHONAPTERA.}

Pulicidae.

Xenopsylla cheopsi, Roths. The commonest rat flea; large numbers have been collected from the following species of rats:--Epimys norvegicus, Mus rattus and Mus alexandrinus. The giant rat (Cricetomys gambianus) and a shrew (Pachyura murina) are also heavily infested.

Ctenocephalus canis, Curtis. On dogs and in houses in town. Large numbers have been taken from goats, and it occasionally attacks man.

Ctenocephalus felis, Bouché. From cats.

\section{SARCOPSYLIIDAE.}

Dermatophilus penetrans, L. Common throughout the two islands; I have taken them on two occasions from dogs.

Echidnophaga gallinacea, Westw. Very common on fowls, the bare parts of the head and the region around the eyes being often thickly encrusted. Several specimens have been taken from the common town rats.

\section{Order RHYNCHOTA.}

Cimicidae.

Cimex hemiptera, F. The tropical bed-bug is to be found everywhere throughout the two islands. At times it is a veritable scourge in the prisons.

Cimex lectularius, L. This insect is extremely rare in Zanzibar. Our collection contains a few specimens, all captured from one Goanese, who had resided for some years in the town.

\section{Order ANOPLURA. \\ Haematopinidae.}

Haematopinus tuberculatus, N. Common on domesticated buffaloes.

Liognathus vituli, L. From calf.

Pediculidae.

Pediculus humanus, L. A common pest among Indians, rarely found on native Africans. 


\section{Order MALLOPHAGA.}

\section{Philopteridae.}

Nirmus varius, N. From a crow (Corvus splendens).

\section{LIOTHEIDAE.}

Colpocephalum subaequale, N. From a crow (Corvus splendens).

Laemobothrium titan, Piaget. From a kite (Milvus aegyptius).

\section{Order ACARINA.}

IXODIDAE.

Rhipicephalus appendiculatus, Neum. The commonest species on cattle; undoubtedly the carrier of African coast fever.

Rhipicephalus simus, Koch. Taken on cattle and donkeys.

Rhipicephalus sanguineus, Latr. Very common on dogs.

Rhipicephalus evertsi, Neum. Common on cattle, goats and sheep. Generally found around the anus or in the ears.

Rhipicephalus pulchellus, Gerst. A rare form in Zanzibar. Numbers can be found on cattle imported from the Somali Coast, including replete females. This tick, probably owing to climatic conditions, has been unable to acclimatise itself on the Island; no specimens have been obtained from local stock.

Rhipicephalus maculatus, Neum. From domesticated pig.

Boophilus decoloratus, Koch. Abundant on cattle.

Boophilus australis, Fuller. From local cattle.

Amblyomma variegatum, F. Taken from cattle, goats, sheep and camels.

Amblyomma hebraeum, Koch. A rare species; a few have been obtained from cattle.

Hyalomma aegyptium, L. A number have been collected from camels; on other domesticated animals they seem to be rare. I am inclined to think that this species, like $R$. pulchellus, has been unable to acclimatise itself.

Haemaphysalis leachi, Aud. Very common on dogs.

Haemaphysalis bispinosa, Warb. From imported Indian cows.

My thanks are due to Mr. Guy A. K. Marshall, Director of the Imperial Bureau of Entomology, and the various experts of the British Museum, who have so promptly identified all material submitted to them. 


\section{$2 \mathrm{BHL}$ Biodiversity Heritage Library}

Aders, W M. 1917. "Insects injurious to man and stock in Zanzibar." Bulletin of entomological research 7, 391-401. https://doi.org/10.1017/S0007485300018095.

View This Item Online: https://www.biodiversitylibrary.org/item/41149

DOI: https://doi.org/10.1017/S0007485300018095

Permalink: https://www.biodiversitylibrary.org/partpdf/7489

\section{Holding Institution}

Smithsonian Libraries

\section{Sponsored by}

Smithsonian

\section{Copyright \& Reuse}

Copyright Status: NOT_IN_COPYRIGHT

This document was created from content at the Biodiversity Heritage Library, the world's largest open access digital library for biodiversity literature and archives. Visit BHL at https://www.biodiversitylibrary.org. 